\title{
Research on the International Exchange and Cooperation in Education under the BRI Based on Review of the Documentary Materials
}

\author{
Zhiyun Cai \\ School of Music, Huanggang Normal University, Huanggang, Hubei, China
}

\begin{abstract}
Based on case analyses of educational exchange between China and the Soviet Union in 1950s recorded in documentary materials, this study probes into the ways to establish, under the guidance of "the Belt and Road Initiative", cultural diplomatic relations and educational cooperation among countries and regions along the Belt and Road by giving a chronological study of China's cultural diplomacy. And on that basis, it further explores how cultural exchange and international relations connect and influence each other with an analysis from both diachronic and synchronic perspectives. This study will provide academic support for the Belt and Road countries to carry out cultural exchanges, and it is particularly instructive for them to explore new ways and countermeasures of educational exchange.
\end{abstract}

Keywords: the Belt and Road Initiative, educational exchange, Soviet experts, documentary materials, artists studying in the Soviet Union

\section{Introduction}

In October 2019, Ministry of Education of People's Republic of China proposed that we need to "strengthen research communication and comparative studies on education between China and foreign countries, draw experience from advanced teaching and educational research achievements from abroad, expand cooperation with foreign educational research institutes as well as enhance communication and cooperation among countries and regions along 'the Belt and Road"'(referred to as "the B\&R countries and regions" hereafter) ${ }^{[1]}$. It is worth noting that the proposal of this strategy fully reflects China's close attention to international cultural exchanges.

As a major member of B\&R countries, Russia has kept close contact with China in cultural exchange and cooperation. 2019 marks the $70^{\text {th }}$ anniversary of the founding of the People's Republic of China; it is also an important stage in the development of Sino-Russian relations since the two countries has established diplomatic relations for 70 years. As a key part in maintaining the comprehensive strategic partnership of coordination between China and Russia, cultural and educational exchanges are positive in enriching the connotation of SinoRussian relations, laying a solid foundation for Sino-Russian relations and pushing forward Sino-Russian relations to the next level. Culture is not only the soul of a country or a nation, but also the symbol of its soft power. International cultural exchanges has reached an unprecedented level in this era of globalization, and the collision and conflict between cultures are also heating up. Cultural diplomacy has since become the center of the international political arena, playing a key role in promoting the integration and development of human civilizations.

In the history of China's cultural diplomacy, the upsurge of cultural and educational exchanges between China and the Soviet Union in the 1950s is of great significance. It not only helps bring the two countries closer, but also lays a solid foundation for China's international talents training. The current research in this field focus mainly on reviewing the background of the exchange, its effect, or giving a chronological account of the exchange in a certain period; few has discussed the valued experience and inspiration we could draw from history to carry out cultural exchanges under the background of "the Belt and Road Initiative"(referred to as "under the BRI" hereafter). Therefore, with a review of China's cultural diplomacy with Russia, and case studies on Sino-Soviet cultural exchanges on education, especially art education in certain historical periods, this paper analyses how international

ISSN: 0010-8189

(C) CONVERTER 2020

www.converter-magazine.info 
relations and political forces influence China's cultural diplomacy, and summarizes achievements and valued experience gained in the practice of China's cultural exchanges with the Soviet Union, which can serve as a reference to international talents training and cultural exchange between China and the B\&R countries.

\section{Sino-Soviet Cultural Exchange in 1950s}

\subsection{Historical Background of Sino-Soviet Cultural Exchange}

In October 1949, the People's Republic of China was founded. The Soviet Union was the first country to recognize and establish diplomatic relations with China. At that time, China, like the Soviet Union, was a socialist country established after a long period of revolutionary struggle. They share the same social system and mainstream ideology; people of the two countries were living in the same social environment and shared the same values ${ }^{[2]}$.

Chinese scholar has once pointed out that "the international environment in which a country is located and its foreign policies made accordingly are one of the most important factors in formulating its policies on international educational exchange" ${ }^{\text {"[3] }}$. In view of the international situation at that time, on February $14^{\text {th }}$, 1950 , leaders of the Communist Party of China signed the Treaty of Friendship, Alliance and Mutual Assistance Between the People's Republic of China and the Union of Soviet Socialist Republics (shortened as Sino-Soviet Treaty of Friendship) in Moscow $^{[4]}$. On March $27^{\text {th }}, 1950$, China and the Soviet Union signed the Agreement on the Conditions for Soviet Experts to Work in China, which symbolized the beginning of cultural exchanges and friendly cooperation between the two countries, and also started an upsurge for China to learn from Soviet experts ${ }^{[5]}$. In the following decade, "learning from the Soviet Union" became one of the main subjects in Chinese academic field, and Soviet experts offered important advice for China to advance its education as well as perfect its teaching system.

Two years later, on September $1^{\text {st }}, 1952$, China and the Soviet Union signed the Agreement on the Study of Chinese Citizens in Soviet Institutions of Higher Learning, according to which selected Chinese students or young teachers were sent successively to the Soviet Union for further study. From 1952 to 1957, as the relations between the two countries stepped into the "honeymoon period", Sino-Soviet cultural and educational exchange was also about to reach its peak, manifested by more frequent exchange of overseas students, employment of education experts, mustual visits of education groups, and translation of books in education, etc. China's "transplant" style of learning from the Soviet Union back then exerted an enormous effect on and was of long-term inspiration for China's cultural undertakings, unparalleled by any other recorded cultural exchange between China and foreign countries. "In addition, for some reason, political or ideological, Russian culture enjoys the most special relationship with China among all western cultures. ${ }^{,[6]}$, It was a state-dominated cultural exchange between China and the Soviet Union, a highly political, most formal and systematic cultural exchange in the history of the two countries ${ }^{[7]}$, playing an important role in promoting the construction of education system in China.

\subsection{The Mass Fervor of Studying in the Soviet Union among Chinese}

16 years of Sino-Soviet cultural exchange from 1950 to 1966 witnessed a great mass fervor of studying in the Soviet Union among Chinese. The central government sent altogether 8,310 people including college students, postgraduates and teachers to the Soviet Union for advanced studies. They were distributed in more than 200 universities and research institutions located in over 20 cities of the Soviet Union, furthering their study in more than 40 majors such as art, machinery, hydropower, petroleum, iron \& steel making, aviation, etc., which are badly in need of talents in China.

On August $19^{\text {th }}, 1951$, China's first batch of 375 international students, among which 136 are college students, started their journey of study to the Soviet Union ${ }^{[8]}$. However, they were confronted with many challenges and difficulties as a result of lack of experience, hasty preparation and zero exposure to Russian after they got there. Therefore in 1952 when China relaunched the program, it adhered to the selection principle of "fewer but better", established the preparatory school, strictly selected candidates to be included in the program, and finally sent 220

ISSN: 0010-8189

(C) CONVERTER 2020

www.converter-magazine.info 
international students to study in the Soviet Union. The following table is a record of international students sent to the Soviet Union in 1951 and 1952.

Table 1 The number of Chinese students sent to study in the Soviet Union (1951-1952)

\begin{tabular}{|c|c|c|c|c|}
\hline Year of stay & College students & Postgraduates & Teachers & Total \\
\hline 1951 & 239 & 136 & 0 & 375 \\
\hline 1952 & 209 & 11 & 0 & 220 \\
\hline
\end{tabular}

—extracted from History of Chinese Overseas Education (after 1949): 220-224 ${ }^{\text {[9] }}$

The number of Chinese students studying in the Soviet Union was on the rise from 1953 to 1956 when Sino-Soviet relations entered the "honeymoon period" (refer to Table 2 for more details). Since 1953, China has clearly put forward the nationwide unified selection standards for preparatory students to study in the Soviet Union, which is also the first time that the Ministry of Education has promulgated the unified national selection standard, making it clear that political, educational, physical qualifications and age limit are imperative for candidates. Strict and specific rules of selection ensured that only gifted talents with "loyalty, enterprising spirit, positive thinking, good character, strong sense of discipline, research spirit and academic potentialities" can be included in the program. In 1954, 1,375 students were sent to study in the Soviet Union. In 1955, it was proposed that more graduates, less or no senior high school students should be selected as candidates, and 1,932 students were sent to the Soviet Union that year. In 1956, the number grew to 2,085.

Table 2 The number of Chinese students sent to study in the Soviet Union (1953-1956)

\begin{tabular}{|c|c|c|c|c|c|}
\hline Year of stay & College students & Postgraduates & Teachers & $\begin{array}{c}\text { International } \\
\text { students of fine arts }\end{array}$ & Total \\
\hline 1953 & 523 & 60 & 0 & 8 & 583 \\
\hline 1954 & 1226 & 149 & 0 & 22 & 1375 \\
\hline 1955 & 1660 & 239 & 33 & 23 & 1932 \\
\hline 1956 & 1343 & 619 & 123 & 13 & 2085 \\
\hline \multicolumn{7}{r}{} \\
\cline { 2 - 5 }
\end{tabular}

From 1957 to 1959 , with worsening Sino-Soviet relations, China asked for more focus on quality instead of scale for the program, as a result of which the number of international students studying in the Soviet Union dropped dramatically, as is shown in Table 3.

Table 3 The number of Chinese students sent to study in the Soviet Union (1957-1959)

\begin{tabular}{|c|c|c|c|c|c|}
\hline Year of stay & $\begin{array}{c}\text { College } \\
\text { students }\end{array}$ & Postgraduates & Teachers & $\begin{array}{c}\text { International } \\
\text { students of fine arts }\end{array}$ & Total \\
\hline 1957 & 40 & 269 & 174 & & 483 \\
\hline 1958 & 8 & 235 & 135 & & 378 \\
\hline 1959 & 65 & 300 & 95 & & 460 \\
\hline
\end{tabular}

The Sino-Soviet relation has been deteriorating since 1960 until it was terminated in 1966. In this period there were altogether 519 Chinese international students sent to study in the Soviet Union, a sharp decline in number compared with that in the previous periods (refer to Table 4 for more details). From July $17^{\text {th }}$ to September $1^{\text {st }}$, 1960, the central plenary session of the Soviet Communist Party announced the recall of nearly 1,390 Soviet experts in China. The assignment of students to the Soviet Union is inevitably affected by the change of relations between the two parties and the two countries. The immediate effect of the changes in the international situation, general and specific policies for studying abroad was most evidently shown in the dramatic decline in the number of Chinese international students studying in the Soviet Union.

ISSN: 0010-8189

(C) CONVERTER 2020

www.converter-magazine.info 
In May, 1966, China terminated the program of sending students to study in the Soviet Union as a result of the rupture pf Sino-Soviet relations.

Table 4 The number of Chinese students sent to study in the Soviet Union (1960-1966)

\begin{tabular}{|c|c|c|c|c|c|}
\hline Year of stay & College students & Postgraduates & Teachers & Interns & Total \\
\hline 1960 & 158 & 66 & 93 & 0 & 317 \\
\hline 1961 & 8 & 30 & 36 & 0 & 74 \\
\hline 1962 & 0 & 30 & 16 & 9 & 55 \\
\hline 1963 & 0 & 15 & 1 & 0 & 17 \\
\hline 1964 & 0 & 3 & 28 & 0 & 3 \\
\hline 1965 & 0 & 25 & 27 & 0 & 138 \\
\hline 1965 & 47 & 64 & \multicolumn{2}{|c|}{-extracted from History of Chinese Overseas Education (after 1949): 220-224 }
\end{tabular}

It is readily seen that the craze among Chinese to study in the Soviet Union in the early days of the People's Republic of China is dominated by the act of two states. Thus the relationship between the two countries has immediate impact on their cultural exchanges. The number of students studying in the Soviet Union is directly proportional to the development of Sino-Soviet relations from the "honeymoon period" to its termination, as is shown in the following figure. The Sino-Soviet cultural exchange dominated by the two governments is inevitably affected by the ups and downs of the relationship between the two countries.

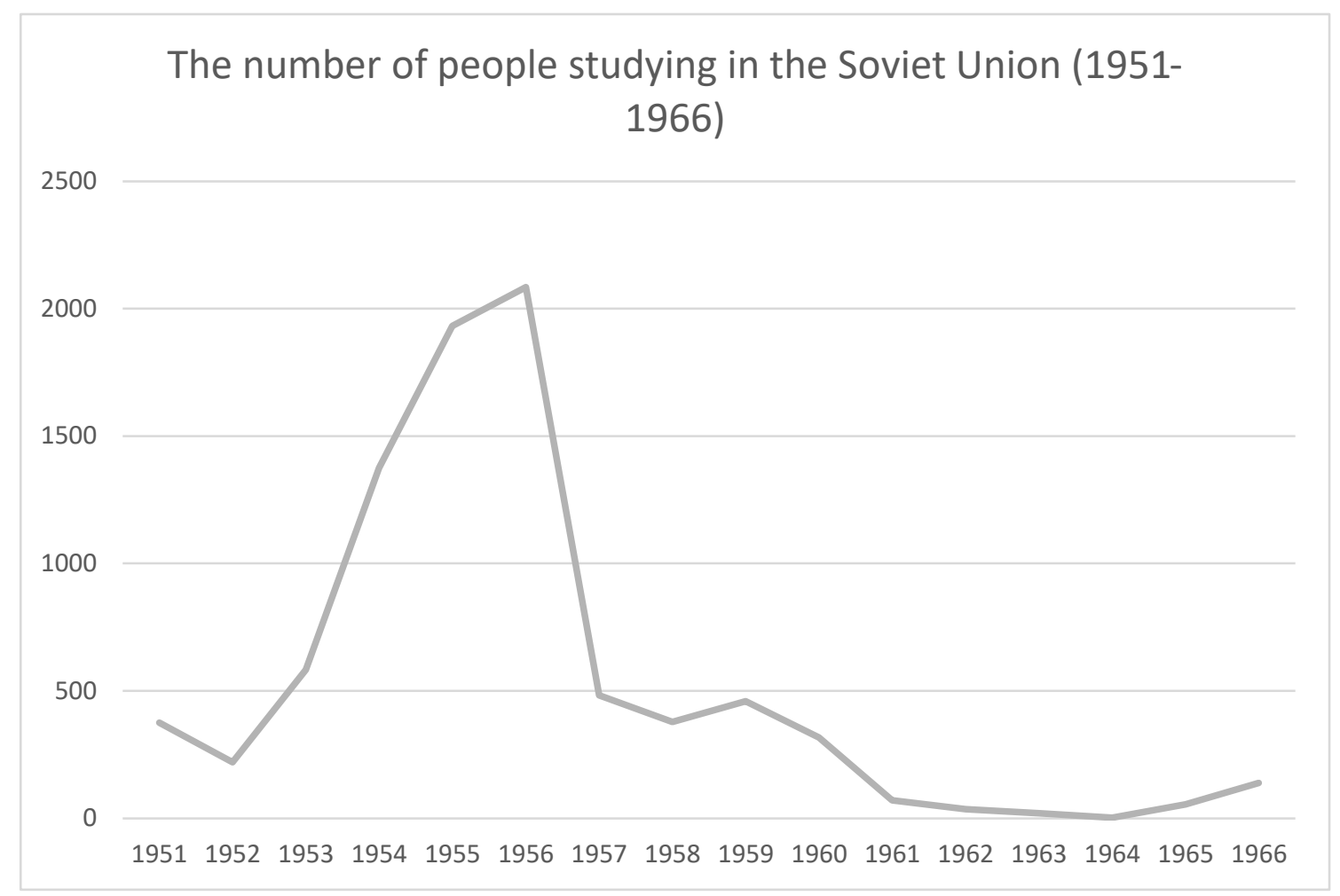

Fig 1: The number of people studying in the Soviet Union (1951-1966)

Although there are ups and downs in the tide of studying in the Soviet Union, its positive effect on the cultural development of new China can not be underestimated. In the field of fine arts, for example, during this upsurge, the Chinese government sent 77 international students to study art in the Soviet Union ${ }^{[10]}$.

Most of the music majors sent by the Ministry of Culture and the Ministry of Education to the Soviet Union study in Moscow's Tchaikovsky Conservatory of Music, Leningrad Conservatory of Music and other professional

ISSN: 0010-8189

(C) CONVERTER 2020

www.converter-magazine.info 
institutions of higher learning. In 1953, the first group to study music in the Soviet Union included Wu zuqiang, Guo Shuzhen and Li Delun. The second group dispatched in 1954 included Du Mingxin, Huang Xiaohe, Xu Yi, Liu Zhigang, Ni Hongjin, Yan Liangkun and Lin Yingrong. After that, China successively sent more art students to the Soviet Union, including non-degree students Qu Wei, Zou Lu, Meili Qige and Zhu Jian'er, Zuo Yin and Cao Chengyun of harp major, Cao Peng, Zheng Xiaoying and Huang Xiaotong of symphony conductor, Zhong Wei of vocal music, Situ Zhiwen and Sheng Mingyao of cello major, Li Minduo of piano major, Han Li and Wu Feifei of violin major, Liu Shikun, Sheng Zhongguo and Lin Yaoji of short-term study. In Leningrad Conservatory of Music there were also a group of Chinese international students studying art there, i.e., Han Zhongjie, Yin Chengzong, Han Zhongnian, Zhu Tongde, Chen Genmin, Bai Yu, etc. In addition, there was Zhu Li who studied violin at Odessa Conservatory of Music in Ukraine ${ }^{[11]}$. (refer to Appendix 1 for more information)

From 1953 to 1965, China's Ministry of Culture and Ministry of Education sent seven batches of students in art major, a total of 33 in number, to the Soviet Union (including majors in painting, sculpture, art history, drama and film stage art, etc.). The first batch set off to the Soviet Union in 1953; it was a group of 4 art students: Li Tianxiang, Qian Shaowu, Cheng Yongjiang and Chen Zun. The second batch followed their journey the next year: 5 art students including Lin Gang, Quan Shanshi, Xiao Feng, Qi Mu'er and Zhou Zheng. The third batch (sent in 1955) were 12 art students: Luo Gongliu, Deng Shu, Guo Shaogang, Wang Baokang, Zhou Benyi, Ma Yunhong, Ji Xiaoqiu, Li Yulan (Chenpeng), Shao Dazhen, Xi Jingzhi, Li baonian and Xu Minghua. The fourth batch (left in 1956) were 5: Feng Zhen, Zhang Huaqing, Li Jun, Wu Biduan, Tan Yongtai. The fifth, sixth, and seventh batches were only groups of 2 art students respectively, and they are Dong Zuyi and Xu Zhiping (left for the Soviet Union in 1957), Cao Chunsheng and Su Gaoli (left in 1960), Situ Zhaoguang and Wang Keqing (left in 1961). Apart from the above 32 students, there were also Li Chun, who studied as a major of art history \& theory in Moscow State University, Lv Zhichang, Liu Xinghou and Zhou Kun, who studied art design for films in Moscow Film Institute $^{[12]}$. (refer to Appendix 2 for more information)

These artists received formal collegiate education in Soviet institutions of higher learning, laid a solid foundation in their specialized fields, and came home to engage in art teaching and research in colleges, research institutes and art troupes in different regions of China. Among them are lots of eminent artists such as composer Wu Zuqiang and Du Mingxin of the Central Conservatory of Music, pianist Liu Shikun, violinist Sheng Zhongguo, musicologist Huang Xiaohe, Li Tianxiang, Lin Gang, Luo Gongliu and Deng Shu of the Central Academy of Fine Arts, Quan Shanshi and Xiao Feng of the China Academy of Art, etc. They have become the backbone in the development of Chinese art, and also played an important role in training art talents in China ${ }^{[13]}$. Thus the trend of studying in the Soviet Union in the early days of new China, with such a large scale and an enormous effect, has proved to be a unique case in Chinese history of education, sending students to study abroad as well as international cultural exchanges.

\subsection{Soviet experts and students sent to China}

It is difficult to give an accurate number of Soviet experts working in China at that time, because firstly there was no agreement on what is "Soviet expert"; secondly time limit for exchanges varies from one expert to another, and besides, the statistics were incomplete. According to China's archival documents, 10,260 Soviet experts were hired to work in China from the eve of the founding of the People's Republic of China to the end of 1958, including 615 Soviet teachers serving in China from 1948 to $1960^{[14]}$.

In his speech at the seminar on graduation works of students of composition department of Central Conservatory of Music, Soviet expert Arabov mentioned: "experts coming to China for public diplomacy were carefully selected by the Soviet government. They would be investigated in terms of political records and professional competence. Every candidate was expected to fill in forms to ensure his political integrity, after which he would be talked to and officially assigned tasks. In addition to political integrity, they were also required to maintain high level of artistic competence, for they were responsible for disseminating advanced achievements and experiences of the development of Soviet art." ${ }^{\text {"[15] }}$ All Soviet art experts sent to China came from institutions of higher learning in their

ISSN: 0010-8189

(C) CONVERTER 2020

www.converter-magazine.info 
country. During this period, the Soviet Union sent educational experts to teach in Chinese colleges and universities to improve their teaching level, so as to help advance the cultural development of China. As Ma Xulun, a Chinese scholar, said: "in the five years since the founding of the People's Republic of China, the achievements we've made in higher education, together with those in other major undertakings in China, are indispensable from the disinterested assistance of our great friend, the Soviet Union. ${ }^{\text {"[16] }}$

Besides, the Soviet Union started to send international students to China in 1954, and 25 students were dispatched to China from 1954 to 1956 (refer to Table 5 for specifics).

Table 5 The number of Soviet students sent to China (1954-1956)

\begin{tabular}{|c|c|c|c|}
\hline Year & 1954 & 1955 & 1956 \\
\hline Number & 18 & 4 & 3 \\
\hline
\end{tabular}

From 1957 to 1965 , the Soviet Union sent a total of 183 students to China ${ }^{[17]}$. These students mainly studied in the majors of Chinese and humanities. The following table takes a record of the number of Soviet international students sent to China in this period.

Table 6 The number of Soviet students sent to China (1957-1965)

\begin{tabular}{|c|c|c|c|c|c|c|c|c|c|}
\hline Year & 1957 & 1958 & 1959 & 1960 & 1961 & 1962 & 1963 & 1964 & 1965 \\
\hline Number & 80 & 10 & 21 & 0 & 21 & 20 & 0 & 13 & 18 \\
\hline
\end{tabular}

The cultural exchange between China and the Soviet Union in the early days of the People's Republic of China boomed in a specific historical period, and was determined by the relations between the two countries ${ }^{[18]}$. It was in turn the key to advancing Sino-Soviet relations. Chinese scholar Xu Xiaoming claimed that "from a historical point of view, the upsurge of Sino-Soviet educational exchange in this period is natural political results of the development of the cultural exchanges between the two states and nations, and in the meantime it was a sign of maturity for China's diplomacy." ${ }^{[19]}$

\section{Reflection on the Sino-Soviet Exchange}

\subsection{Educational exchange lays the foundation for cultural exchange}

"Cultural diplomacy" is an expression first included in the 1934 edition of Oxford English Dictionary. According to this entry, "the British Parliament has created a new means of cultural diplomacy, which is devoted to promoting overseas English teaching". The focus of a country's cultural diplomacy now is not limited to the popularization of its language. Some Chinese experts believes that "it refers to purposeful exchanges, usually based on culturerelated activities, with certain foreign countries led by the government or official organizations" ${ }^{, 20]}$.

As a key part of the cultural diplomatic strategies of the two countries, the upsurge of Sino-Soviet exchanges in the early days of the founding of the People's Republic of China (1949-1966) is closely related to China's economic development at that time. Sending students to study in the Soviet Union, on the one hand, fills the gap left by the shortage of talents in China, and on the other hand, it provides long-term support for China to march towards the socialist modernization by means of drawing on advanced experiences in management and technological development from the Soviet Union ${ }^{[21]}$. Moreover, the assistance China has received from Soviet experts and the dispatch of international students help the two countries communicate and cooperate with each other both intensively and extensively in politics, economy, culture and other fields, making significant breakthroughs and also setting a pattern for international talents training in the future.

As an old saying in China goes, "By setting bronze as a mirror one can adjust dressing; by setting history as a mirror one knows ups and downs of a dynasty". We can set the history of Sino-Soviet relations as a mirror and reference for the future development of the bilateral relations between China and Russia. By studying the history of

ISSN: 0010-8189

(c) CONVERTER 2020

www.converter-magazine.info 
Sino-Soviet cultural exchanges, we may avoid repeated mistakes, draw lessons and gain inspirations from it so as to ensure a long-term development of Sino-Russian relations as well as offer a pattern that could be used for reference in developing bilateral relations with "the Belt and Road" countries. We believe that one can "draw

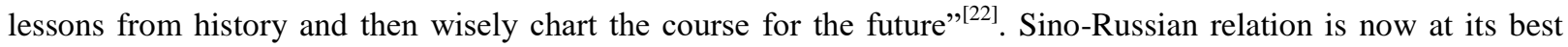
since the establishment of diplomatic relations between the two countries. It is on the basis of experiences and lessons learned from the past that the two countries can harmoniously cooperate with each other and make common progress. Therefore, it is in a sense a sample of great value for modern strategic research.

\subsection{International relations influence policy-making}

At the beginning of the founding of new China, the exchanges between China and the Soviet Union are basically official and follow the rule of unified leadership and centralized management, which are conducive to the unified planning, management and resource allocation of China's cultural exchanges under the guidance of its foreign policy and cultural policy. In this way China is able to see the world and have itself better shown to the world ${ }^{[23]}$. Yet the Sino-Soviet cultural exchange has not been easy, "the primary concern about the identification of ideology and social system has resulted in limited alternatives for sending states (mainly from the Soviet Union), but deficiencies in the management system, manifested by the state-run, internal-control management, determined that the exchange was affected by political relations between the two countries" ${ }^{\text {"[24] }}$, argued Chinese scholar Li Peng. Some scholars in China further argued that "politics is the most influential factor in the Sino-Soviet exchanges in the 1950s; it has a direct impact on the dispatch of international students to the Soviet Union as well as the introduction of Soviet experts to work in China. In addition to the political relations between the two countries, other factors that influence cultural diplomacy may include its historical background and national psychology" ${ }^{\text {"[25] }}$. According to Chinese scholar Shen Zhihua, "the ultimate cause of the disputes between the two countries lies in their unequal status and power in the Sino-Soviet relations" ${ }^{\text {"[26] }}$. Obviously it is inevitable that international relations exert great influence on cultural exchanges between countries.

\subsection{The imbalance of cultural exchange leads to hidden troubles}

In July, 1945, it was pointed out by Chinese national leader that "China is in a situation of economic and cultural backwardness" ${ }^{\text {"[27] }}$. Back then many other Chinese leaders echoed this statement, acknowledging the backwardness of Chinese culture and advocating active learning from the Soviet Union. Thus it can be seen that compared with Chinese culture, Soviet culture was in a superior position at that time, and to China, the exchange focused on absorbing and learning from the Soviet Union, featuring much more of cultural input than cultural export. In other words, influenced by the international situation, together with the comparatively slow economic development and weak overall national strength of China, its cultural exchange with other countries is more likely to be drawing on and internalizing the experience and achievements of these countries ${ }^{[28]}$. "Imbalance is the root cause of SinoSoviet disputes" ${ }^{\text {[29] }}$. The cultural and educational exchange between China and the Soviet Union is not exactly twoway communication.

The imbalance of cultural exchanges is commonly seen in history, and usually it will lead to hidden problems in the development of international relations. Cultural diplomacy dominated by the government should attach equal importance to "cultural import" and "cultural export". The "import" and "export" need to be synchronized and conducted based on equality, mutual benefit and respect. Different countries, by means of communication and drawing on valued experience from each other, will ultimately fulfill the task of "cultural import" and "cultural export", and thus deepen their mutual understanding, share their views and engage in closer and more in-depth cooperation with one another.

\subsection{Ways and forms of cultural exchange are limited}

From the history of China's cultural exchange with foreign countries, we know that in the mid-nineteenth century, influenced by the international situation, China adopted the policy of "standing firmly on socialist side", which

ISSN: 0010-8189

(C) CONVERTER 2020

www.converter-magazine.info 
determined that it mainly had cultural exchanges with the USSR in limited ways of communication. While nowadays globalization has broken the shackles of politics in cultural exchange, resulting in diversified forms and elements of cultural exchange. As an important form of cultural exchange, educational exchange has occupied a dominant position in a country's cultural diplomacy. It has become popular all around the world and influences almost all areas of society, advancing to a large extent communication and cooperation between different cultures as well as bringing about increasingly significant changes in the setup and order of world culture ${ }^{[30]}$. Therefore, different from Sino-Soviet educational exchange, the current educational exchange in China, under the guidance of "the Belt and Road Initiative", can be carried out both intensively and extensively in much more flexible ways such as the exchange of international students and teachers, international academic conferences, visiting scholars, educational collaborative projects, mutual visits of educational groups, translation and introduction of educational works, distance education and internet courses, etc ${ }^{[31]}$.

\section{Approaches and Strategies for Cultural Diplomacy under the BRI.}

In 2016, the Ministry of Culture of the People's Republic of China proposed the "2016-2020 Action Plan on the Cultural Development under the BRI", making it clear that China's cultural diplomacy follows the basic principles of government dominance, openness and inclusiveness, communication and mutual learning, innovative development, market regulation and mutual benefits. It focuses on perfecting mechanisms of and building better platforms for BRI cultural communication and cooperation, creating BRI brands of cultural exchanges, promoting the prosperity of BRI cultural industries and advancing BRI trade cooperation ${ }^{[32]}$. This proposition has reflected well the wishes of and the general trend for China to carry out cultural exchanges with the B\&R countries.

There are two reasons for the study on educational exchanges under the BRI: in terms of its role in facilitating cultural dissemination, educational exchange is so important that it has proved in the history of human civilization to be needed by all nations to help diversify their cultures, and there is no substitute for it in bridging international cooperation; and in terms of its role in facilitating the advance of history, educational exchange is undoubtedly a logical choice for accelerating globalization as well as fostering mutual trust and integration of all peoples in the world.

Any country, for the purpose of seeking cultural progress and social development, is bound to promote educational exchanges with foreign countries. In the age of globalization marked by advanced technology and IT application, educational exchange as a unique cultural activity of human beings is more and more likely to be common in international communication. It contributes not only to the enhancement of overall national strength, competitive power, national cohesion, creativity and confidence of the BRI countries, but also to the improvement of their educational standards as well as to the accumulation of their cultural traditions. Therefore, based on past experience, we will expound on the significance of and strategies for educational exchange under the BRI from the following three aspects.

\subsection{Advocating BRI educational Exchange is an important approach of cultural diplomacy}

Culture is the essence of a country; education is the key to national prosperity and people's happiness. Cultural diplomacy is essential to shaping and boosting a country's international image, improving international relations, reinforcing mutual understanding and consensus among different countries, disseminating the native culture and at the same time absorbing and integrating excellent foreign cultures. Educational exchange, as an important channel of cultural diplomacy, creates a fine cultural atmosphere for the realization of the Belt and Road initiative. It is not only able to help strengthen the cultural consciousness and cultural confidence of countries along the Belt and Road, but also help them develop mutual interest, establish stable, lasting relationships, and avoid tensions among them ${ }^{[33]}$. Moreover, through the exchange of values and cross-cultural education, it will enhance mutual understanding, learning and personnel exchange among the BRI countries, and consequently build a more dynamic atmosphere for cultural and educational exchanges among them, enabling different civilizations to benefit from each other in mutual learning and reach the goal of common prosperity.

ISSN: 0010-8189

(c) CONVERTER 2020

www.converter-magazine.info 
From the global perspective, the advocation of educational exchange will advance cooperation among the BRI countries featuring equality, mutual benefit and vitality as well as comprehensively improve regional international influence. From a national perspective, it can help enhance the soft power of the BRI countries and regions, leaving them a space for survival and progress while experiencing cultural collision and cultural cooperation in this age of globalization $^{[34]}$. From a cultural perspective, it connects all countries and has an undeniable effect on strengthening mutual understanding, playing a key role in increasing communication, eliminating cultural differences and reducing cultural conflicts ${ }^{[35]}$. From a political perspective, it is a harmonious and healthy way of communication among different countries.

\subsection{Improving BRI cooperation mechanisms is a requisite for cultural diplomacy}

In the practice of cultural diplomacy under the BRI, government dominance is the major foundation of promoting cultural exchanges; safeguarding national interests is an important principle to be followed while dealing with international relations. Government-led diplomatic actions will unavoidably be affected by political interests implicated in international relations; hence we need to keep in mind lessons gained in the Sino-Soviet exchanges, i.e., all countries, in the course of cultural exchanges, should try to seek common ground while shelving differences, respect each other and safeguard their own rights and interests. BRI countries and regions, with a vision of building a community of shared future for mankind, and in order to provide effective support to the cultural development under the initiative, should align their strategic planning, promote political negotiations, actively sign and implement intergovernmental agreements on cultural cooperation, make medium- and long-term cooperation plan with joint efforts, build a sound framework and mechanism of educational cooperation, as well as improve the relevant law and regulation system of cultural exchange.

The best way to maintain international relations is to follow the rule of mutual political trust, equality and mutual benefit. In the 1950s, due to the absence of mutual trust and instability of Chinese society, ideological disputes and differences arose in the process of exchange between China and the Soviet Union, which resulted in a breach in the Sino-Soviet relations. We learn from this past experience that it is on the basis of equality and mutual benefit, together with communication and negotiation, that long-term exchanges among different countries can be guaranteed.

\subsection{Building BRI platforms of exchange is a practical approach of cultural diplomacy}

In recent years, Chinese leaders have put forward the idea of building a community of shared future for mankind. The growing interdependence among countries entails a community of shared interests, responsibility and destiny ${ }^{[36]}$. For the fulfillment of this task, China is now actively promoting the implementation of the Initiative by means of reinforcing communication among BRI countries and regions, integrating BRI regional resources, bolstering common development of regional cultures, building new platforms as well as exploring new ways of exchange and cooperation in accordance with the principles of mutual respect, justice and win-win cooperation. To be specific, we need to:

Firstly, enhance policy coordination among the B\&R countries, create more platforms of cultural exchange and educational cooperation, and explore new ways of communication with the aid of modern technologies such as multimedia and network.

Secondly, accelerate the construction of cultural center in the B\&R countries and regions. Overseas cultural centers and embassies of China should work closely to build the frontline of its cultural diplomacy, transforming themselves into multi-functional entities that provide needed information for countries along the Belt and Road and accordingly promoting the dissemination of different cultures among them. By performing their duties, which mainly includes offering information service, organizing cultural activities and educational training, they open the window for countries to get an up-close look at other cultures, give full play to the function of transmitting cultures

ISSN: 0010-8189

(c) CONVERTER 2020

www.converter-magazine.info 
as well as bridging all peoples to enhance their mutual understanding and friendship, and thus play a positive role in developing friendly relations between China and the B\&R countries.

Last but not least, explore new approaches and models of cultural diplomacy with concerted efforts. The B\&R countries should expand cultural and educational exchange and cooperation, facilitate cultural exchange among non-governmental organizations under the guidance of the governments, coordinate their policies of cultural exchange and integrate themselves into the globalized world.

\section{Conclusion}

There is a long history of China's international cultural exchange, yet it has been uneasy. Social and political factors in certain historical periods exert enormous influence on the practice and development of China's cultural diplomacy; strategies for exchange also vary along with the changes of international situation. In recent years China has made remarkable achievements in developing intercultural relations, consolidating international friendship, enhancing mutual understanding, sharing brilliant culture, promoting cooperation with other countries for common development. However, there are still some imperfections to be further improved.

Therefore, we propose that with the goal of building a community of shared future for mankind, the B\&R countries and regions should base their cultural and educational exchange on equality and intergovernmental political trust, and meanwhile establish a sound cooperation mechanism and exchange system, create more platforms of exchange and introduce more ways of cooperation. With lessons gained in the past experience, this study works out new thoughts and new approaches of cultural diplomacy, providing academic support for the B\&R countries to get revitalized through cultural exchange. It is highly instructive for establishing a global system featuring openness, inclusiveness, cooperation and mutual benefit as well as upgrading the "soft power" of the B\&R countries in an all-round way.

\section{Acknowledgments}

This research was supported by:

1) Industry-University Collaborative Education Project entitled "Research on Innovation of Training Mode of Art Teachers through Industry-University Collaboration from an International Perspective", which was granted by Ministry of Education of China (Grant No. 201802202020).

2) Philosophy and Social Science Project granted by the Education Department of Hubei Province, entitled "Research on the Artistic Dissemination of Huangmei Opera along the Silk Road" (Grant No. 19Q178).

3) High-level Research Project granted by Huanggang Normal University, entitled "Research on the Training Mode of Music Talents Sent to Study in the Soviet Union in the Early Days of the PRC" (Grant No. 201908403).

4) Teaching Research Project granted by Huanggang Normal University, entitled "Research on Intercollegiate Exchanges in Teaching Innovation Practice of Music Majors from an International Perspective" (Grant No. 2019CE66).

\section{References}

[1] Ministry of Education of the People's Republic of China, "Opinions on Strengthening Educational Scientific Research in the new era," 2019-10-30.

[2] Y.B. Tao, "Historical Review of and Reflection on the Sino-Russian Exchanges in Music," Beijing: People's Music Publishing House, 2011.

[3] Z.X. Yu, Z.Y. Liu, C .Zhang, "The Evolution of Sino-Russian (Sino-Soviet) Educational Exchange," Jinan: Shandong Education Press, 2010.

[4] X.Z. Liu, "A historical Review of the Establishment of Sino-Russian Diplomatic Relations since 1949 and Issues to Be Focused on in Its Future Development,". Academic Journal of Russian Studies, vol. 9, no. 4, pp. 58-73, 2019.

ISSN: 0010-8189

(C) CONVERTER 2020

www.converter-magazine.info 
[5] R. Li, "Sino-Soviet Music Communication from the Perspective of Sociology," Harbin: Harbin Normal University, 2011.

[6] Y.D. Yang, "Dialogues: Reflection on Chinese Music Influenced by Russian and Soviet Music," Music Research, vol. 5, pp. 75, 2012.

[7] J.H. Zhang, "Overseas Students Studying in the Soviet Union in 1950s and 1960s \& Soviet Image in Their Eyes," Overseas Chinese History Studies, vol. 1, pp. 52-60, 2018.

[8] T. Li, "Lessons \& Progress: A Study of Sino-Soviet Educational Relations (1949-1976)," Hangzhou: Zhejiang Education Press, 2006.

[9] T. Li, "History of Chinese Overseas Education (after 1949)," Beijing: Higher Education Press, 2000.

[10] Y. Wang, "A Study of Chinese Musicians' Composition during Their Stay in the Soviet Union in 1950s," Harbin: Harbin Normal University, 2011.

[11] X.H. Huang, "Unforgettable Moments in the Soviet Union," Arts Criticism, vol. 6, pp. 41-47, 2009.

[12] H.Q. Zhang, "The Upsurge of Studying in Soviet Union and Art of the New China," China Art Weekly, 2013-3-9.

[13] C.J. Li, "Localization of Chinese Oil Painting from 1900 to 2000," Beijing: People's Publishing House, 2017.

[14] Z.H. Shen, "A Historical Review of Soviet-expert Issues: General Situation \& Policy Changes," Contemporary China History Studies, vol. 1, pp. 24-37, 2002.

[15] Arts and Cultural Activities, Archives of the Central Conservatory of Music, vol. 73, 1955.

[16] X.L. Ma, "Higher Education of the New China in the Past Five Years," People's Education, vol. 10, pp. 15-16, 1954.

[17] F.Z. Yu, B. Jiang, X.Y. Zhu, "History of International Educational Exchange and Cooperation," Haikou: Hainan Publishing House, 2002.

[18] S.W. Zhou, "A Review of the Upsurge of Studying in the Soviet Union in the Early Days of the Founding of the People's Republic of China," Studies on Mao Zedong and Deng Xiaoping Theories, vol. 10: pp. 49-54, pp. 115, 2012.

[19] X.M. Xu, "China's Cultural Diplomacy under the Background of Globalization," Guiyang: Guizhou Normal University, 2009.

[20] T.T. Li, "Cultural Exchange under the Belt and Road Initiative," Beijing: Chinese National Academy of Arts, 2016.

[21] P. Li, "A Historical Review of the Upsurge of Studying in the Soviet Union in the Early Days of the New China," Shanghai: East China Normal University, 2008.

[22] Z.H. Shen, "An Outline of the History of Sino-Soviet Relations (1917-1991)," Beijing: Xinhua Publishing House. 2007.

[23] L.J. Zhou, "International Cultural Exchange and Diplomacy of New China," Beijing: Culture and Art Publishing House, 2010.

[24] P. Li, "A Historical Review of the Upsurge of Studying in the Soviet Union in the Early Days of the New China," Shanghai: East China Normal University, 2008.

[25] Y.X. Guo, Y. Yao, "Inspirations from Soviet Experts in China," Historical Studies of Chinese Economy, vol. 2, pp. 103-107, 2006.

[26] Z.H. Shen, "An Outline of the History of Sino-Soviet Relations (1917-1991)," Beijing: Xinhua Publishing House, 2007.

[27] Z.D. Mao, “Collected Writings of Mao Zedong (the $7^{\text {th }}$ Vol.),"Beijing: People's Publishing House, 1999.

[28] D.D. Zhang, "Characteristics of China's Cultural Exchange with Foreign Countries in 1950s," Contemporary China History Studies, vol. 21, 6, pp. 52-60, pp. 126, 2014.

[29] X.P. Deng, "Collected Works of Deng Xiaoping (the $3^{\text {rd }}$ Vol.)," Beijing: People's Publishing House, 2001.

ISSN: 0010-8189 
[30] J.B. Luo, "Outlining Cutural Strategy for China to Rise," Contemporary International Relations, vol. 3, pp. 35, 2006.

[31] Z.Y. Liu, "Diplomacy vs Studying abroad: Research on the Upsurge of Studying in the Soviet Union in the Late Qing Dynasty," Wuhan: Central China Normal University, 2014.

[32] Ministry of Culture of the People's Republic of China, "2016-2020 Action Plan on the Cultural Development under the BRI," 2016.

[33] http://www.gov.cn/gongbao/content/2017/content_5216447.htm

[34] Laszlo, Ervin (ed.), "The Multicultural Planet: The Report of a UNESCO International Expert Group," Beijing: Social Sciences Academic Press, 2001.

[35] L. Liu, "A Study of Chinese Cultural Diplomacy in the New Century," Beijing: China Foreign Affairs University, 2006.

[36] L.Z. Zeng, "Application of Music in Public Diplomacy," Shanghai: Shanghai International Studies University, 2013.

[37] Q.C. Liu, T.T. Chang, "The Reform of International System and China's Diplomatic Choice," Jilin University Journal (Social Sciences Edition), vol. 59, no. 6, pp. 149-157, pp. 222-223, 2019.

Appendix 1: The list of Chinese musicians sent to study in the Soviet Union

\begin{tabular}{|l|l|l|l|l|l|l|}
\hline \multicolumn{1}{|c|}{ Name } & Major & $\begin{array}{c}\text { Year of } \\
\text { birth }\end{array}$ & $\begin{array}{c}\text { Year of } \\
\text { stay }\end{array}$ & $\begin{array}{c}\text { Year of } \\
\text { return }\end{array}$ & $\begin{array}{l}\text { Target institutions \& } \\
\text { universities }\end{array}$ & \multicolumn{1}{|c|}{$\begin{array}{l}\text { Workplace upon } \\
\text { return }\end{array}$} \\
\hline $\begin{array}{l}\text { Wu } \\
\text { Zuqiang }\end{array}$ & Composition & 1927 & 1953 & 1958 & $\begin{array}{l}\text { Moscow's Tchaikovsky } \\
\text { Conservatory of Music }\end{array}$ & $\begin{array}{l}\text { Central Conservatory } \\
\text { of Music }\end{array}$ \\
\hline Li Delun & Conducting & 1917 & 1953 & 1957 & $\begin{array}{l}\text { Moscow's Tchaikovsky } \\
\text { Conservatory of Music }\end{array}$ & $\begin{array}{l}\text { Central Orchestra } \\
\text { (predecessor of China } \\
\text { National Symphony } \\
\text { Orchestra) }\end{array}$ \\
\hline $\begin{array}{l}\text { Guo } \\
\text { Shuzhen }\end{array}$ & Vocal music & 1927 & 1953 & 1958 & $\begin{array}{l}\text { Moscow's Tchaikovsky } \\
\text { Conservatory of Music }\end{array}$ & $\begin{array}{l}\text { China Conservatory } \\
\text { of Music }\end{array}$ \\
\hline $\begin{array}{l}\text { Du Mingxin } \\
\text { Ni Hongjin }\end{array}$ & Composition & 1928 & 1954 & 1958 & $\begin{array}{l}\text { Moscow's Tchaikovsky } \\
\text { Conservatory of Music }\end{array}$ & $\begin{array}{l}\text { Central Conservatory } \\
\text { of Music }\end{array}$ \\
\hline $\begin{array}{l}\text { Piano } \\
\text { Yingrong }\end{array}$ & Cello & 1935 & 1954 & 1959 & $\begin{array}{l}\text { Moscow's Tchaikovsky } \\
\text { Conservatory of Music }\end{array}$ & $\begin{array}{l}\text { Central Conservatory } \\
\text { of Music; China } \\
\text { Conservatory of } \\
\text { Music; People's } \\
\text { Liberation Army } \\
\text { Academy of Art }\end{array}$ \\
\hline $\begin{array}{l}\text { Liu } \\
\text { Zhigang }\end{array}$ & Bassoon & - & 1954 & - & $\begin{array}{l}\text { Moscow's Tchaikovsky } \\
\text { Conservatory of Music }\end{array}$ & $\begin{array}{l}\text { Mepartment of } \\
\text { Military Culture, } \\
\text { National Defense } \\
\text { University PLA } \\
\text { China }\end{array}$ \\
\hline
\end{tabular}

ISSN: 0010-8189

(C) CONVERTER 2020

www.converter-magazine.info 
CONVERTER MAGAZINE

Volume 2021, No. 4

\begin{tabular}{|c|c|c|c|c|c|c|}
\hline $\begin{array}{l}\text { Huang } \\
\text { Xiaohe }\end{array}$ & $\begin{array}{l}\text { Violin \& } \\
\text { Musicology }\end{array}$ & 1935 & 1954 & 1961 & $\begin{array}{l}\text { Moscow's Tchaikovsky } \\
\text { Conservatory of Music }\end{array}$ & $\begin{array}{l}\text { Central Conservatory } \\
\text { of Music }\end{array}$ \\
\hline $\begin{array}{l}\text { Yan } \\
\text { Liangkun }\end{array}$ & Conducting & 1923 & 1954 & 1958 & $\begin{array}{l}\text { Moscow's Tchaikovsky } \\
\text { Conservatory of Music }\end{array}$ & Central Chorus \\
\hline Zhu Jian'er & Composition & 1922 & 1955 & 1960 & $\begin{array}{l}\text { Moscow's Tchaikovsky } \\
\text { Conservatory of Music }\end{array}$ & $\begin{array}{l}\text { Central Studio of } \\
\text { News Reels } \\
\text { Production; Shanghai } \\
\text { Opera House; } \\
\text { Shanghai Symphony } \\
\text { Orchestra }\end{array}$ \\
\hline Qu Wei & Composition & 1917 & 1955 & 1959 & $\begin{array}{l}\text { Moscow's Tchaikovsky } \\
\text { Conservatory of Music }\end{array}$ & $\begin{array}{l}\text { Shanghai Symphony } \\
\text { Orchestra }\end{array}$ \\
\hline Zou Lu & Composition & 1927 & 1955 & 1960 & $\begin{array}{l}\text { Moscow's Tchaikovsky } \\
\text { Conservatory of Music }\end{array}$ & $\begin{array}{l}\text { Sichuan Provincial } \\
\text { Art College } \\
\text { (predecessor of } \\
\text { Sichuan } \\
\text { Conservatory of } \\
\text { Music) }\end{array}$ \\
\hline $\begin{array}{l}\text { Huang } \\
\text { Xiaotong }\end{array}$ & Conducting & 1933 & 1955 & 1960 & $\begin{array}{l}\text { Moscow's Tchaikovsky } \\
\text { Conservatory of Music }\end{array}$ & $\begin{array}{l}\text { Shanghai } \\
\text { Conservatory of } \\
\text { Music }\end{array}$ \\
\hline Cao Peng & Conducting & 1925 & 1955 & 1961 & $\begin{array}{l}\text { Moscow's Tchaikovsky } \\
\text { Conservatory of Music }\end{array}$ & $\begin{array}{l}\text { Shanghai Symphony } \\
\text { Orchestra; Shanghai } \\
\text { Conservatory of } \\
\text { Music }\end{array}$ \\
\hline Zhong Wei & Vocal music & 1921 & 1955 & 1962 & $\begin{array}{l}\text { Moscow's Tchaikovsky } \\
\text { Conservatory of Music }\end{array}$ & $\begin{array}{l}\text { China Conservatory } \\
\text { of Music }\end{array}$ \\
\hline Meili Qige & Composition & 1928 & 1956 & 1958 & $\begin{array}{l}\text { Moscow's Tchaikovsky } \\
\text { Conservatory of Music }\end{array}$ & $\begin{array}{l}\text { Inner Mongolia } \\
\text { Ethnic Opera Troupe }\end{array}$ \\
\hline $\begin{array}{l}\text { Han } \\
\text { Zhongjie }\end{array}$ & Conducting & 1920 & 1957 & 1961 & $\begin{array}{l}\text { Leningrad } \\
\text { Conservatory of Music }\end{array}$ & $\begin{array}{l}\text { Central Opera House; } \\
\text { Central Orchestra; } \\
\text { Central Conservatory } \\
\text { of Music }\end{array}$ \\
\hline Lin Yaoji & Violin & 1937 & 1960 & 1962 & $\begin{array}{l}\text { Moscow's Tchaikovsky } \\
\text { Conservatory of Music }\end{array}$ & $\begin{array}{l}\text { Central Conservatory } \\
\text { of Music }\end{array}$ \\
\hline Liu Shikun & Piano & 1939 & 1960 & 1962 & $\begin{array}{l}\text { Moscow's Tchaikovsky } \\
\text { Conservatory of Music }\end{array}$ & $\begin{array}{l}\text { Central Conservatory } \\
\text { of Music }\end{array}$ \\
\hline $\begin{array}{l}\text { Yin } \\
\text { Chengzong }\end{array}$ & Piano & 1941 & 1960 & 1963 & $\begin{array}{l}\text { Leningrad } \\
\text { Conservatory of Music }\end{array}$ & $\begin{array}{l}\text { Central Orchestra } \\
\text { (piano virtuoso) }\end{array}$ \\
\hline Zhu Tongde & Flute & 1930 & 1960 & 1964 & $\begin{array}{l}\text { Leningrad } \\
\text { Conservatory of Music }\end{array}$ & $\begin{array}{l}\text { Central Conservatory } \\
\text { of Music }\end{array}$ \\
\hline Bai Yu & Oboe & 1940 & 1960 & 1965 & $\begin{array}{l}\text { Leningrad } \\
\text { Conservatory of Music }\end{array}$ & $\begin{array}{l}\text { Central Conservatory } \\
\text { of Music }\end{array}$ \\
\hline Li Minduo & Piano & 1939 & 1960 & - & $\begin{array}{l}\text { Moscow's Tchaikovsky } \\
\text { Conservatory of Music }\end{array}$ & $\begin{array}{l}\text { Shanghai } \\
\text { Conservatory of } \\
\text { Music }\end{array}$ \\
\hline $\begin{array}{l}\text { Zheng } \\
\text { Xiaoying }\end{array}$ & Conducting & 1929 & 1960 & 1963 & $\begin{array}{l}\text { Moscow's Tchaikovsky } \\
\text { Conservatory of Music }\end{array}$ & $\begin{array}{l}\text { Central Conservatory } \\
\text { of Music; Central } \\
\text { Opera Orchestra }\end{array}$ \\
\hline Zuo Yin & Harp & - & 1960 & - & Moscow's Tchaikovsky & Central Conservatory \\
\hline
\end{tabular}

ISSN: 0010-8189

C CONVERTER 2020

www.converter-magazine.info 
CONVERTER MAGAZINE

Volume 2021, No. 4

\begin{tabular}{|l|l|l|l|l|l|l|}
\hline $\begin{array}{l}\text { Sheng } \\
\text { Zhongguo }\end{array}$ & Violin & 1941 & 1960 & 1964 & $\begin{array}{l}\text { Monservatory of Music } \\
\text { Conservatory of Music }\end{array}$ & of Music \\
\hline He Fuxing & Clarinet & 1939 & 1960 & 1963 & $\begin{array}{l}\text { Leningrad } \\
\text { Conservatory of Music }\end{array}$ & Central Orchestra \\
\hline $\begin{array}{l}\text { Zhao } \\
\text { Pingguo }\end{array}$ & Piano & 1932 & 1960 & 1962 & $\begin{array}{l}\text { Leningrad } \\
\text { Conservatory of Music }\end{array}$ & $\begin{array}{l}\text { Central Conservatory } \\
\text { of Music }\end{array}$ \\
\hline Situ Zhiwen & Cello & 1933 & 1960 & - & $\begin{array}{l}\text { Moscow's Tchaikovsky } \\
\text { Conservatory of Music }\end{array}$ & $\begin{array}{l}\text { Cellist, music } \\
\text { educator \& first class } \\
\text { of national player }\end{array}$ \\
\hline Zhu Li & Violin & - & 1962 & - & $\begin{array}{l}\text { Odessa Conservatory } \\
\text { of Music }\end{array}$ & $\begin{array}{l}\text { Opera Troupe of PLA } \\
\text { General Political } \\
\text { Department }\end{array}$ \\
\hline Han Li & Violin & - & 1962 & - & $\begin{array}{l}\text { Moscow's Tchaikovsky } \\
\text { Conservatory of Music }\end{array}$ & $\begin{array}{l}\text { Central Conservatory } \\
\text { of Music }\end{array}$ \\
\hline Bian Meng & Piano & 1955 & 1990 & 1996 & $\begin{array}{l}\text { Leningrad } \\
\text { Conservatory of Music }\end{array}$ & $\begin{array}{l}\text { Central Conservatory } \\
\text { of Music }\end{array}$ \\
\hline $\begin{array}{l}\text { Qian } \\
\text { Banping }\end{array}$ & $\begin{array}{l}\text { Appreciation } \\
\text { of Music } \\
\text { Works }\end{array}$ & 1946 & 1990 & 1991 & $\begin{array}{l}\text { Moscow's Tchaikovsky } \\
\text { Conservatory of Music }\end{array}$ & $\begin{array}{l}\text { Shanghai } \\
\text { Conservatory of } \\
\text { Music }\end{array}$ \\
\hline $\begin{array}{l}\text { Zhang } \\
\text { Guoyong }\end{array}$ & $\begin{array}{l}\text { Conducting } \\
\text { (PS: Dus }\end{array}$ & 1958 & 1993 & 1997 & $\begin{array}{l}\text { Moscow's Tchaikovsky } \\
\text { Conservatory of Music }\end{array}$ & $\begin{array}{l}\text { Shanghai Opera } \\
\text { House }\end{array}$ \\
\hline
\end{tabular}

(PS: Due to incompleteness of data, the year of birth and return of some musicians are unknown)

Appendix 2: The list of Chinese artists sent to study in the Soviet Union

\begin{tabular}{|l|l|c|c|c|l|l|}
\hline \multicolumn{1}{|c|}{ Name } & \multicolumn{1}{|c|}{ Major } & $\begin{array}{c}\text { Year of } \\
\text { birth }\end{array}$ & $\begin{array}{c}\text { Year of } \\
\text { stay }\end{array}$ & $\begin{array}{l}\text { Year of } \\
\text { return }\end{array}$ & $\begin{array}{l}\text { Target institutions } \\
\text { \& universities }\end{array}$ & \multicolumn{1}{|c|}{$\begin{array}{c}\text { Workplace upon } \\
\text { return }\end{array}$} \\
\hline $\begin{array}{l}\text { Li } \\
\text { Tianxiang }\end{array}$ & Oil Painting & 1928 & 1953 & 1959 & $\begin{array}{l}\text { Repin Academy of } \\
\text { Fine Arts }\end{array}$ & $\begin{array}{l}\text { Central Academy of } \\
\text { Fine Arts; }\end{array}$ \\
\hline $\begin{array}{l}\text { Qian } \\
\text { Shaowu }\end{array}$ & Sculpture & 1928 & 1953 & 1959 & $\begin{array}{l}\text { Repin Academy of } \\
\text { Fine Arts }\end{array}$ & $\begin{array}{l}\text { School of Fine Arts, } \\
\text { Shanghai University }\end{array}$ \\
\hline $\begin{array}{l}\text { Chen } \\
\text { Zunsan }\end{array}$ & Printmaking & 1929 & 1953 & 1959 & $\begin{array}{l}\text { Repin Academy of } \\
\text { Fine Arts }\end{array}$ & $\begin{array}{l}\text { Lu Xun Academy of } \\
\text { Fine Arts }\end{array}$ \\
\hline $\begin{array}{l}\text { Cheng } \\
\text { Yongjiang }\end{array}$ & Art History & 1932 & 1953 & 1959 & $\begin{array}{l}\text { Repin Academy of } \\
\text { Fine Arts }\end{array}$ & $\begin{array}{l}\text { Central Academy of } \\
\text { Fine Arts }\end{array}$ \\
\hline $\begin{array}{l}\text { Lin Gang } \\
\text { Quan }\end{array}$ & Oil Painting & 1925 & 1954 & 1959 & $\begin{array}{l}\text { Repin Academy of } \\
\text { Fine Arts }\end{array}$ & $\begin{array}{l}\text { Central Academy of } \\
\text { Fine Arts }\end{array}$ \\
\hline Shanshi & Oil Painting & 1930 & 1954 & 1960 & $\begin{array}{l}\text { Repin Academy of } \\
\text { Fine Arts }\end{array}$ & $\begin{array}{l}\text { China Academy of } \\
\text { Art }\end{array}$ \\
\hline $\begin{array}{l}\text { Xiao Feng } \\
\text { Qil Painting }\end{array}$ & 1932 & 1954 & 1960 & $\begin{array}{l}\text { Repin Academy of } \\
\text { Fine Arts }\end{array}$ & $\begin{array}{l}\text { China Academy of } \\
\text { Art }\end{array}$ \\
\hline $\begin{array}{l}\text { Qi Mudong } \\
\text { Zheng }\end{array}$ & Stage Art & 1922 & 1954 & 1957 & $\begin{array}{l}\text { Repin Academy of } \\
\text { Fine Arts }\end{array}$ & $\begin{array}{l}\text { The Central } \\
\text { Academy Of Drama }\end{array}$ \\
\hline $\begin{array}{l}\text { Li Chun } \\
\text { Ohou }\end{array}$ & $\begin{array}{l}\text { Criticism } \\
\text { World Art }\end{array}$ & 1934 & 1954 & 1959 & $\begin{array}{l}\text { Repin Academy of } \\
\text { Fine Arts }\end{array}$ & $\begin{array}{l}\text { China Youth Art } \\
\text { Theatre }\end{array}$ \\
\hline
\end{tabular}

ISSN: 0010-8189

(C) CONVERTER 2020

www.converter-magazine.info 
CONVERTER MAGAZINE

Volume 2021, No. 4

\begin{tabular}{|c|c|c|c|c|c|c|}
\hline & Art Theory & & & & & \\
\hline $\begin{array}{l}\text { Luo } \\
\text { Gongliu }\end{array}$ & Oil Painting & 1916 & 1955 & 1958 & $\begin{array}{l}\text { Repin Academy of } \\
\text { Fine Arts }\end{array}$ & $\begin{array}{l}\text { Central Academy of } \\
\text { Fine Arts }\end{array}$ \\
\hline Deng Shu & Oil Painting & 1929 & 1955 & 1961 & $\begin{array}{l}\text { Repin Academy of } \\
\text { Fine Arts }\end{array}$ & $\begin{array}{l}\text { Central Academy of } \\
\text { Fine Arts }\end{array}$ \\
\hline $\begin{array}{l}\text { Guo } \\
\text { Shaogang }\end{array}$ & Oil Painting & 1932 & 1955 & 1960 & $\begin{array}{l}\text { Repin Academy of } \\
\text { Fine Arts }\end{array}$ & $\begin{array}{l}\text { Guangzhou Academy } \\
\text { of Fine Arts }\end{array}$ \\
\hline $\begin{array}{l}\text { Xu } \\
\text { Minghua }\end{array}$ & Oil Painting & 1932 & 1955 & 1960 & $\begin{array}{l}\text { Repin Academy of } \\
\text { Fine Arts }\end{array}$ & $\begin{array}{l}\text { Nanjing Normal } \\
\text { University }\end{array}$ \\
\hline Zhou Benyi & Stage Art & 1931 & 1955 & 1960 & $\begin{array}{l}\text { Repin Academy of } \\
\text { Fine Arts }\end{array}$ & $\begin{array}{l}\text { Shanghai Theatre } \\
\text { Academy }\end{array}$ \\
\hline Ji Xiaoqiu & Stage Art & 1931 & 1955 & 1961 & $\begin{array}{l}\text { Repin Academy of } \\
\text { Fine Arts }\end{array}$ & $\begin{array}{l}\text { Art Troupe of PLA } \\
\text { General Political } \\
\text { Department }\end{array}$ \\
\hline $\begin{array}{l}\text { Wang } \\
\text { Baokang }\end{array}$ & Stage Art & 1923 & 1955 & 1961 & $\begin{array}{l}\text { Repin Academy of } \\
\text { Fine Arts }\end{array}$ & $\begin{array}{l}\text { Central Academy of } \\
\text { Drama }\end{array}$ \\
\hline $\begin{array}{l}\text { Ma } \\
\text { Yunhong }\end{array}$ & Stage Art & 1930 & 1955 & 1961 & $\begin{array}{l}\text { Repin Academy of } \\
\text { Fine Arts }\end{array}$ & $\begin{array}{l}\text { Central Academy of } \\
\text { Drama; Central } \\
\text { Academy of Craft } \\
\text { Art }\end{array}$ \\
\hline Li Baonian & Sculpture & 1933 & 1955 & 1960 & $\begin{array}{l}\text { Leningrad Musina } \\
\text { Institute of Higher } \\
\text { Arts \& Crafts } \\
\text { (predecessor of } \\
\text { Saint Petersburg Art } \\
\text { and Industry } \\
\text { Academy }\end{array}$ & $\begin{array}{l}\text { Central Academy of } \\
\text { Craft Art }\end{array}$ \\
\hline Li Yulan & Art History & 1933 & 1955 & 1960 & $\begin{array}{l}\text { Repin Academy of } \\
\text { Fine Arts }\end{array}$ & $\begin{array}{l}\text { Institute of Fine Arts } \\
\text { of China; Central } \\
\text { Academy of Fine } \\
\text { Arts }\end{array}$ \\
\hline $\begin{array}{l}\text { Shao } \\
\text { Dazhen }\end{array}$ & Art History & 1934 & 1955 & 1960 & $\begin{array}{l}\text { Repin Academy of } \\
\text { Fine Arts }\end{array}$ & $\begin{array}{l}\text { Central Academy of } \\
\text { Fine Arts }\end{array}$ \\
\hline Xi Jingzhi & Art History & 1935 & 1955 & 1960 & $\begin{array}{l}\text { Repin Academy of } \\
\text { Fine Arts }\end{array}$ & $\begin{array}{l}\text { Central Academy of } \\
\text { Craft Art }\end{array}$ \\
\hline Wu Biduan & Printmaking & 1926 & 1956 & 1959 & $\begin{array}{l}\text { Repin Academy of } \\
\text { Fine Arts }\end{array}$ & $\begin{array}{l}\text { Central Academy of } \\
\text { Fine Arts }\end{array}$ \\
\hline Feng Zhen & Oil Painting & 1931 & 1956 & 1962 & $\begin{array}{l}\text { Repin Academy of } \\
\text { Fine Arts }\end{array}$ & $\begin{array}{l}\text { Central Academy of } \\
\text { Fine Arts }\end{array}$ \\
\hline Li Jun & Oil Painting & 1931 & 1956 & 1962 & $\begin{array}{l}\text { Repin Academy of } \\
\text { Fine Arts }\end{array}$ & $\begin{array}{l}\text { Central Academy of } \\
\text { Fine Arts }\end{array}$ \\
\hline $\begin{array}{l}\text { Zhang } \\
\text { Huaqing }\end{array}$ & Oil Painting & 1932 & 1956 & 1962 & $\begin{array}{l}\text { Repin Academy of } \\
\text { Fine Arts }\end{array}$ & Nanjing Arts Institute \\
\hline $\begin{array}{l}\text { Tan } \\
\text { Yongtai }\end{array}$ & Art History & 1934 & 1956 & 1960 & $\begin{array}{l}\text { Repin Academy of } \\
\text { Fine Arts }\end{array}$ & $\begin{array}{l}\text { Zhejiang Academy of } \\
\text { Fine Arts }\end{array}$ \\
\hline Dong Zuyi & Sculpture & 1934 & 1957 & 1963 & $\begin{array}{l}\text { Repin Academy of } \\
\text { Fine Arts }\end{array}$ & $\begin{array}{l}\text { Central Academy of } \\
\text { Fine Arts }\end{array}$ \\
\hline Xu Zhiping & $\begin{array}{l}\text { Preservation \& } \\
\text { Restoration of } \\
\text { Ancient Fine }\end{array}$ & 1928 & 1957 & 1960 & $\begin{array}{l}\text { Repin Academy of } \\
\text { Fine Arts }\end{array}$ & $\begin{array}{l}\text { Museum of Chinese } \\
\text { Revolution }\end{array}$ \\
\hline
\end{tabular}

ISSN: 0010-8189

C CONVERTER 2020

www.converter-magazine.info 
CONVERTER MAGAZINE

Volume 2021, No. 4

\begin{tabular}{|c|c|c|c|c|c|c|}
\hline & Arts & & & & & \\
\hline Su Gaoli & Oil Painting & 1937 & 1960 & 1966 & $\begin{array}{l}\text { Repin Academy of } \\
\text { Fine Arts }\end{array}$ & $\begin{array}{l}\text { Central Academy of } \\
\text { Fine Arts }\end{array}$ \\
\hline $\begin{array}{l}\text { Cao } \\
\text { Chunsheng }\end{array}$ & Sculpture & 1937 & 1960 & 1964 & $\begin{array}{l}\text { Repin Academy of } \\
\text { Fine Arts }\end{array}$ & $\begin{array}{l}\text { Central Academy of } \\
\text { Fine Arts }\end{array}$ \\
\hline $\begin{array}{l}\text { Wang } \\
\text { Keqing }\end{array}$ & Sculpture & 1933 & 1961 & 1963 & $\begin{array}{l}\text { Repin Academy of } \\
\text { Fine Arts }\end{array}$ & $\begin{array}{l}\text { Central Academy of } \\
\text { Fine Arts }\end{array}$ \\
\hline $\begin{array}{l}\text { Situ } \\
\text { Zhaoguang }\end{array}$ & Sculpture & 1940 & 1961 & 1966 & $\begin{array}{l}\text { Repin Academy of } \\
\text { Fine Arts }\end{array}$ & $\begin{array}{l}\text { Central Academy of } \\
\text { Fine Arts }\end{array}$ \\
\hline
\end{tabular}

